\title{
Priority ranking of road sites for mitigating wildlife roadkill
}

\author{
Alex Bager $^{1,3}$ \& Clarissa Alves da Rosa ${ }^{1,2}$ \\ ${ }^{1}$ Grupo de Pesquisa em Ecologia de Estradas, Setor de Ecologia, Departamento de Biologia, \\ Universidade Federal de Lavras - UFLA, Campus Universitário, CP 3037, CEP 37200 000, Lavras, MG, Brasil \\ ${ }^{2}$ Programa de Pós-graduação em Ecologia Aplicada, Universidade Federal de Lavras - UFLA \\ ${ }^{3}$ Autor para correspondência: Alex Bager, e-mail: abager@dbi.ufla.br
}

BAGER, A. \& ROSA, C.A. Priority ranking of road sites for mitigating wildlife roadkill. Biota Neotrop. 10(4): http://www.biotaneotropica.org.br/v10n4/en/abstract?article+bn03010042010.

\begin{abstract}
We propose a ranking index to assign priorities to sites for implementation of measures to mitigate wildlife roadkill. We conducted a case study along $34 \mathrm{~km}$ of highway BR 392 in Southern Brazil. We compared priority sites established only according to roadkill rates, with those defined by our index. The index used four parameters: the richness of target species, diversity of roadkilled species, roadkill rate of target species, and presence of endangered species. Although it is impossible to protect the entire community of vertebrates affected by roadkill, we defined nine target species, five mammals and four reptiles. For each parameter, we defined coefficients ranging between 0 and 3 . There was a significant change in the priorities of sites for implementing mitigation devices, which caused changes in the species that were protected. The definition of priority sites by considering only the roadkill rate protected reptiles especially, to the detriment of all mammal species, including endangered species. Sites with high roadkill rates continued to be among the most important for conservation, but the index diluted the effect of this parameter, changing the ranking. This ranking index can be an effective tool to aid government institutions in decision-making, especially when more elaborate analyses are not feasible for reasons of time, resources, or lack of trained personnel.

Keywords: decision-making, ranking index, mitigation, road ecology, roadkill.
\end{abstract}

BAGER, A. \& ROSA, C.A. Hierarquização de quilômetros prioritários à mitigação de atropelamentos de animais selvagens. Biota Neotrop. 10(4): http://www.biotaneotropica.org.br/v10n4/pt/abstract?article+bn03010042010.

Resumo: Propomos um índice para a definição de trechos prioritários à implantação de medidas de mitigação contra atropelamento de animais selvagens. Conduzimos um estudo de caso em $34 \mathrm{~km}$ da rodovia BR 392, no Sul do Brasil. Comparamos trechos prioritários definidos somente com taxas de atropelamento e trechos prioritários definidos pelo índice. $\mathrm{O}$ índice se utilizou de 4 parâmetros: riqueza de espécies alvo, diversidade total de espécies atropeladas, taxa de atropelamento de espécies atropeladas e presença de espécies ameaçadas. Considerando ser impossível proteger toda a comunidade de vertebrados afetada por atropelamento definimos 9 espécies alvo, 5 mamíferos e 4 répteis. Para cada parâmetro foram definidos coeficientes com valores entre 0 e 3 . Houve uma significativa mudança nos trechos prioritários para implantação de aparatos de mitigação, alterando as espécies que foram protegidas. Os trechos, definidos somente pela taxa de atropelamento, protegeram especialmente répteis, em detrimento de todos os mamíferos, incluindo as espécies ameaçadas. Trechos com altas taxas de atropelamento continuaram entre os mais importantes para conservação, mas o índice diluiu o efeito deste parâmetro, alterando sua prioridade. O índice pode ser uma ferramenta efetiva para a tomada de decisão em instituições governamentais, especialmente quando análises mais elaboradas não são viáveis em razão de tempo, recursos ou ausência de pessoal especializado.

Palavras-chave: tomada de decisão, índice de prioridade, mitigação de impactos, ecologia de estradas, atropelamento. 


\section{Introduction}

Effects of roads on biodiversity are related to the mortality of animals during the construction of a highway, mortality from collision with vehicles, modification in animal behavior, increasing the human use and occupation of the surrounding areas, habitat fragmentation, and introduction of exotic species (Trombulak \& Frissell 2000, Coffin 2007). Of these effects, the most studied in recent years is the roadkills of wild animals (Clevenger et al. 2003, Taylor \& Goldingay 2004, Pinowski 2005, Coelho et al. 2008, Gomes et al. 2009). Accidents occur because the highway cuts through the habitat of the species, interfering with their natural range of movement and resulting in collisions with vehicles (Coffin 2007). In addition, carnivorous scavengers are attracted by the carcasses, increasing the risk of new collisions and generating a continuous cycle of diversity loss (Pinowski 2005). The establishment of measures to mitigate these effects, such as tunnels, fences, and other apparatuses, is always limited by economic considerations. Therefore, ranking of road stretches for the deployment of these devices should be undertaken with caution, so that important areas are not eliminated during the selection process. When this ranking is based simply on the roadkill rate, one or more priority species for conservation are usually overlooked (endangered species, umbrella species, and target species, among others), as well as species richness, the surrounding landscape, and other aspects.

There is a clear distinction between studies done in Brazil and those developed abroad. Brazilian studies seek to establish mitigation strategies for a large number of species (Coelho et al. 2008, GumierCosta \& Sperber 2009, Turci \& Bernarde 2009), normally involving different classes. Outside Brazil, the majority of publications focus on a specific species (Finder et al. 1999, Gomes et al. 2009, Roger \& Ramp 2009), order (Aresco 2005), or class (Hels \& Buchwald 2001). Possibly this difference is related to the existing species richness, or to economic issues as well. In Brazil, it is necessary to increase protection while collecting more data with less financial support; whereas in developed countries, the focus is on protecting one or a few threatened species or to reduce the financial and social costs of wildlife roadkill (Finder et al. 1999).

The identification of hotspots has involved such varied areas as the criminal (Glässer \& Vajihollahi 2008) or health (d'Aignaux et al. 2001), used in the definition of public policies, identification of priority areas for conservation (Myers et al. 2000), and in critical roadkill areas (Ramp et al. 2005, Gomes et al. 2009, Roger \& Ramp 2009). Brazil lacks studies on wildlife roadkill that are aimed at the implementation and evaluation of mitigation measures, and most studies have focused on listing the species that are run over (Bager et al. 2007). Some have sought to identify roadkill hotspots, but these analyses were based solely on roadkill rates. Pereira et al. (2006) and Novelli et al. (1988) studied the distribution of roadkills on each kilometer of highway, whereas Prado et al. (2006) and Gumier-Costa \& Sperber (2009) divided the highways into stretches of five kilometers or more. Coelho et al. (2008) tested the spatial distribution of roadkills, seeking to identify aggregations, without a priori determining the length of the road stretches. All these studies considered only the total richness of species killed on the roads, without focusing on specific taxa.

Based on these facts, we aimed to develop a Ranking Index (RI) covering different aspects of the fauna community affected, and that will allow users to justify to governmental agencies and private companies, the deployment, or otherwise, of measures to protect the fauna killed on roads. The index is intended to be accessible to non-academic users, requiring few computational and mathematical procedures, as a means to expand its use in environmental impact studies. We compared the ranking of kilometer stretches based only on the rate of collisions, with the ranking established by the RI proposed here.

\section{Material and Methods}

The index was tested on a 34-kilometer stretch of highway BR 392, which is paved and runs between Vila da Quinta (Municipality of Rio Grande $-\mathrm{km} 25+400 \mathrm{~m}$ ) and the São Gonçalo Channel (Municipality of Pelotas $-\mathrm{km} 58+400 \mathrm{~m}$ ), in the southern part of the State of Rio Grande do Sul, Brazil. The notation "km $25+400$ m" was based on the official kilometer markings used by the National Department of Transport Infrastructure (Departamento Nacional de InfraEstrutura de Transporte - DNIT) and indicates the beginning point of the kilometer considered. The region is characterized by coastal environments formed by marine and lacustrine deposits of the PatosMirim lagoon complex, featuring wetlands, dry fields, woods, and coastal-dune or swamp forests (Waechter \& Jarenkow 1998).

Roadkill data were obtained from 2002 to 2005, totaling 91 monitoring events. The samples were taken at an average speed of $50 \mathrm{~km} /$ hour, sampling reptiles, birds, and mammals (Bager 2006). Each animal was identified to species or genus, the collection date was noted, and the geographical position obtained with a GPS. One kilometer was divided into 34 sections, and the roadkill data were grouped for each section.

Mitigation devices must be installed in locations where they have the highest probability of being used by the species targeted for impact mitigation, taking into account the main road-killed species, critical areas for roadkill, vulnerability of the species to extinction, and the type of environment associated with the highway (Bekker \& Iuell 2003). Nine target species for impact mitigation were defined. These species were established for the classes of reptiles and mammals; no bird species was sufficiently threatened to include in the class. Five were mammals: Geoffroy's cat (Leopardus geoffroyi) (d'Orbigny \& Gervais, 1844) and the Neotropical river otter (Lontra longicaudis) (Olfers, 1818), because they are threatened with extinction in Rio Grande do Sul (Indrusiak \& Eizirik 2003); nutria (Myocastor coypus Molina, 1782), the mammal most often killed on BR 392; the whiteeared opossum (Didelphis albiventris Lund, 1840), the second most-often killed mammal on BR 392; and the thick-tailed opossum (Lutreolina crassicaudata Desmarest, 1804), a critically endangered species in the State of Rio de Janeiro (Bergallo et al. 2000) and the fourth most-often killed species on BR 392. For the reptiles, four species were defined: the water snake (Helicops infrataeniatus Jan 1865), the species killed most often among all the classes; and for chelonians, Orbigny's slider turtle (Trachemys dorbigni Duméril \& Bibron, 1835), Hilaire's Side-necked Turtle (Phrynops hilarii Duméril \& Bibron, 1835), and the black spiny-necked turtle (Acanthochelys spixii Duméril \& Bibron, 1835), respectively the second, third, and fourth most-often killed species in their class. Acanthochelys spixii has a "Near Threatened" status in the IUCN list (Tortoise \& Freshwater Turtle Specialist Group 1996).

The selection of critical kilometer stretches may be aimed at maintaining ecological processes, protecting both rare species and those most impacted by road kills; or may focus on the species that are most affected, regardless of their importance in the community structure. We sought to merge the two trends by creating a process for ranking kilometers based on an index composed of four parameters: richness of target species; roadkill rate of target species; total diversity; and presence of threatened species.

For each of the parameters that comprise the index, we established four coefficients (0-3) (Table 1$)$ : 
- Richness of target species: number of target species found in the kilometer stretch. For this parameter, the maximum richness value was nine.

- Roadkill rate of target species: the roadkill rate was standardized for the number of animals killed per kilometer*100 during the study period, the maximum value being equal to 4.49 .

- Total diversity (Shannon Index): this parameter incorporated all the species of reptiles, birds, and mammals killed on the kilometer. The maximum diversity was equal to 1.68 .

- Presence of threatened species: this parameter considered that the two endangered species affected by roadkill on BR 392, Lontra longicaudis and Leopardus geoffroyi (Indrusiak \& Eizirik 2003) are large mammals that have a high capacity for movement. Nakano-Oliveira et al. (2004) recorded routine movements of L. longicaudis of about $1 \mathrm{~km}$, and the range of L. geoffroyi is estimated at between 1.8 and $12.4 \mathrm{~km}^{2}$ (Oliveira $\&$ Cassaro 2005). The kilometers with no occurrence of an endangered species in their stretch or in the adjacent kilometers received a score of $0 ; 1$ when at least one endangered species was present in the adjacent kilometer; 2 when one endangered species was present in the kilometer analyzed; and 3 when two endangered species were present in the kilometer analyzed.

We compared the priority kilometers identified by the RI to those established by using the rate of roadkill. We began with the assumption that no road can contain mitigation measures along its entire length, and created cutoff levels (10 to 40\%) based on the highest rate of roadkills (5.2 ind./km*100). Thus, kilometers with a roadkill rate of less than $0.52 \mathrm{ind} . / \mathrm{km} * 100$ were eliminated at the $10 \%$ level, those with rates less than 1.04 ind./km*100 were excluded at the $20 \%$ level, and the procedure was repeated for the other intervals.

\section{Results}

\section{General analysis}

The roadkill rate in each section ranged from 0.065 to 5.2 ind. $/ \mathrm{km}^{*} 100$, with an average of $1.06 \mathrm{ind} . / \mathrm{km} * 100$. There was marked asymmetry, with $73.5 \%$ of the kilometers with roadkill rates less than 1 ind./km*100 $(\mathrm{N}=25)$. The highest number of roadkills, considering all classes, occurred between kilometers $52+400$ and $58+400$. In these kilometers, reptiles were the most affected class, and all the species were from wet or aquatic habitats. Three of the four species that were most often run over along the entire highway (Helicops infrataeniatus, Phrynops hilarii, and Trachemys dorbigni) were also most often killed on this stretch. The exception was Acanthochelys spixii, with $62 \%$ of its kills concentrated in the stretches of $38+400$ to $45+400 \mathrm{~km}$. Mammals were the second mostaffected class, with Myocastor coypus and Lutreolina crassicaudata predominating. The birds, which had the lowest roadkill rates, were represented by Furnarius rufus (Gmelin, 1788) and Pitangus sulphuratus (Linnaeus, 1766).

Table 1. Coefficients established for each parameter of the ranking index on BR 392.

Tabela 1. Coeficientes estabelecidos para cada parâmetro do índice de hierarquização na BR 392.

\begin{tabular}{ccccl}
\hline Points & \multicolumn{4}{c}{ Parameters } \\
\cline { 2 - 5 } & $\begin{array}{c}\text { Richness } \\
\text { (S) }\end{array}$ & $\begin{array}{c}\text { Taxa } \\
\text { (ind./km*100) }\end{array}$ & $\begin{array}{c}\text { Diversity } \\
\text { (H) }\end{array}$ & $\begin{array}{c}\text { Threatened } \\
\text { species }\end{array}$ \\
\hline 0 & $<3$ & $<0.2$ & $<0.6$ & 0 species \\
1 & 3 to 4 & 0.2 to 1.7 & 0.6 to 1 & Adjacent km \\
2 & 5 to 6 & 1.7 to 3.2 & 1 to 1.4 & 1 species \\
3 & $>6$ & $>3.2$ & $>1.4$ & 2 species \\
\hline
\end{tabular}

The selection of kilometers with a $10 \%$ cutoff level resulted in 18 priority kilometers. This number was reduced to 8 at the $20 \%$ level, 6 at $30 \%$, and 5 at $40 \%$. All cutoff levels except the $10 \%$ level concentrated the ranking on kilometers $52+400$ to $58+400 \mathrm{~km}$ (Figure 1).

\section{Ranking index}

The analysis using the ranking index identified 16 priority kilometers, with values that varied between 4 and 8 . Kilometer 47 +400 , classified by the RI with a score of 7 , was not identified as important when only the roadkill rate was used. An additional $3 \mathrm{~km}$, defined within the $10 \%$ level, were not classified as important by the RI. Of the priority kilometers defined by the RI, $38 \%$ were included because of different factors of the roadkill rate.

Two kilometers totaled 8 points $(48+400$ and $55+400 \mathrm{~km})$, with identical values for richness (3) and diversity (2). However, the roadkill rate and the threatened species contributed in different ways. For kilometer $48+400$, the occurrence of roadkills of $L$. longicaudis influenced its ranking, whereas for kilometer $55+400$ the roadkill rate of $5.2 \mathrm{ind} . / \mathrm{km} * 100$ was the determining factor. Using the roadkill rate, kilometer $48+400$ would only fit as a priority in the $10 \%$ cutoff level, and was among the less important stretches for the implementation of mitigation measures.

The kilometers defined exclusively by means of the roadkill rate showed a strong relationship with RI when the cutoff level was $10 \%$ (Table 2). At this level, only one kilometer defined by the RI was not identified by the roadkill rate. However, the $20 \%$ cutoff level, which implies the maintenance of kilometers with roadkill rates above 1.04 ind. $/ \mathrm{km}^{*} 100$, did not select more than half the kilometers with values 7 and 8 in the RI. The RI identified seven kilometers with values of 7 and 8 , and of these, four were not assigned any priority by the roadkill rates. When this cutoff level was extended to $40 \%$, the ranking by roadkill rate failed to select $69 \%$ of the kilometers defined by the RI.

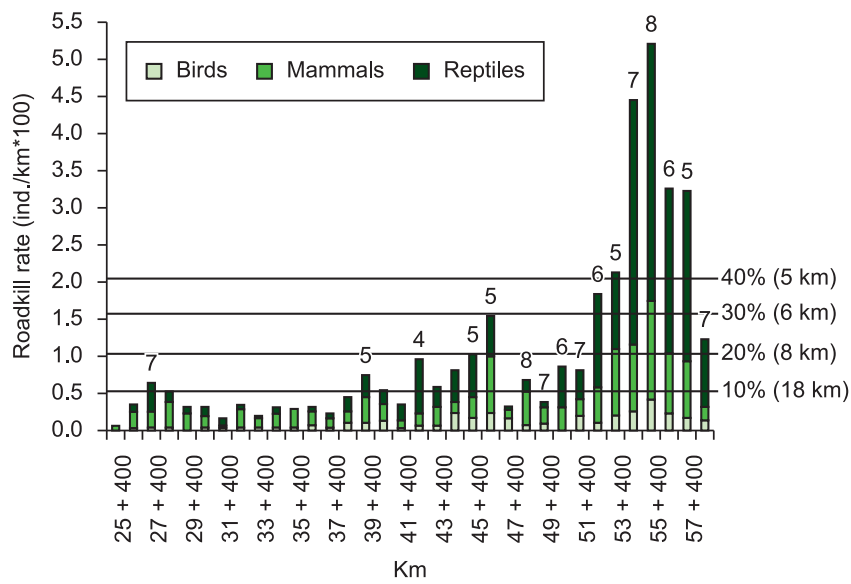

Figure 1. Roadkill rate (ind./km*100) of mammals, birds, and reptiles in the 34-kilometer monitored stretch of BR 392, Rio Grande, State of Rio Grande do Sul. The horizontal lines define the different cutoff levels of priority kilometers when only the roadkill rates are considered. Numbers in parentheses are the number of kilometers in each level selected. Numbers above bars are the values obtained by applying the ranking index.

Figura 1. Taxa de atropelamento (ind./km*100) de mamíferos, aves e répteis nos 34 quilômetros monitorados da BR 392, em Rio Grande, RS. As linhas horizontais definem as diferentes faixas de corte de quilômetros prioritários quando considerada exclusivamente as taxas de atropelamento. Números entre parênteses são o número de quilômetros selecionados em cada faixa. Números sobre as barras são os valores obtidos com a aplicação do índice de hierarquização. 
Table 2. Percentage of kilometers prioritized by the RI and not prioritized by use of the roadkill rates, according to different cutoff levels (10 to 40\%). The values 4-8 represent the RI value, and the numbers in parentheses represent the number of kilometers prioritized.

Tabela 2. Percentual de quilômetros priorizados pelo IH e não priorizados pelas taxas de atropelamentos segundo diferentes faixas de corte (10 a 40\%). Os valores de 4 a 8 representam o valor do $\mathrm{IH}$ e os números entre parênteses o número de quilômetros priorizados.

\begin{tabular}{cccccc}
\hline $\mathbf{( \% )}$ & $\mathbf{8 ( 2 )}$ & $\mathbf{7 ( 5 )}$ & $\mathbf{6 ( 3 )}$ & $\mathbf{5 ( 5 )}$ & $\mathbf{4 ( 1 )}$ \\
\hline 10 & 0.0 & 0.2 & 0.0 & 0.0 & 0.0 \\
20 & 0.5 & 0.6 & 0.3 & 0.4 & 1.0 \\
30 & 0.5 & 0.8 & 0.3 & 0.6 & 1.0 \\
40 & 0.5 & 0.8 & 0.7 & 0.6 & 1.0 \\
\hline
\end{tabular}

\section{Discussion}

The ranking index proved to be an excellent strategy for defining priority stretches for the deployment of devices to protect the fauna. If the establishment of kilometers is based only the roadkill rate, most stretches would protect reptiles, such as H. infrataeniatus, T. dorbigni, A. spixii, and $P$. hilarii, to the detriment of the mammal species and all the endangered species. The kilometers with high roadkill rates continued to be ranked among the most important stretches for conservation, but the RI diluted the effect of this parameter, changing the priority.

The selection of target species was the point that caused the greatest difficulty in defining the RI. The inclusion of $D$. albiventris was fiercely debated, since the species has a wide distribution and high abundance in both natural and anthropogenically altered habitats. The species was retained because of its importance as a seed disperser and because it acts as an important controller of other species of vertebrates and invertebrates (Cáceres 2002).

We suggest that, when available, parameters of richness, diversity, and endangered species in the area surrounding a highway be incorporated into this ranking system. We can explain this statement by our finding that kilometer $38+400$ has three endangered species, Lontra longicaudis, Leopardus geoffroyi, and Tamandua tetradactyla (Linnaeus,. 1758). Tamandua tetradactyla was described for the region during surveys carried out in the vicinity of the highway (Rosa et al. 2010). This kilometer was not prioritized in either of the two methods, demonstrating that information from the community that is directly affected by roadkill may be insufficient for ranking areas. The use of information from the surrounding landscape can also complement the RI (Benítez-López et al. 2010), although we re-emphasize that the purpose of this index is as a tool to facilitate analysis and understanding by different segments of society. Incorporating a large number of factors makes this analysis more difficult, and will also increase the autocorrelation of the variables involved.

Unlike studies that aim to establish predictive models of roadkill (Malo et al. 2004, Gomes et al. 2009, Roger \& Ramp 2009), the RI intends to rank the kilometers and identify those in which the installation of mitigation devices is a priority. The proposal for the RI presented here was developed in one case study, based on sections of one kilometer. This scale was adequate for a preliminary examination, but after the kilometers are identified, it will then be necessary to refine the analysis to define specific locations for the installation of mitigation measures. These measures must consider the affected fauna in the locale, avoiding the use of standardized methods throughout the extent of the study area. Another possibility, because more precise data are available, is to calculate the RI for smaller segments. RI analyses should not be used at scales below $500 \mathrm{~m}$, because of the difficulty of incorporating information such as the movements of endangered species or wildlife in the small area covered.

We believe that this proposal should be tested in different geographical areas and should be adapted to the variables that are identified as most relevant. The RI does not fully substitute for the insight of the team involved in selecting locations for roadkill mitigation, but does play a decisive role in justifying the implementation of their proposals to the environmental agencies.

\section{Acknowledgments}

To the innumerable fellows and interns who assisted in collecting, sorting, and maintaining the database that led to this work, and to the funding institutions, Fundação O Boticário de Proteção à Natureza, FAPERGS, and FAPEMIG.

\section{References}

ARESCO, M.J. 2005. Mitigation measures to reduce highway mortality of turtles and other herpetofauna at a North Florida Lake. J. Wildl. Manag. 69(2):549-560.

BAGER, A. 2006. Avaliação dos impactos das rodovias federais à fauna selvagem no extremo sul do Rio Grande do Sul - Brasil. Projeto Estrada Viva, Universidade Católica de Pelotas, Pelotas. Relatório Técnico.

BAGER, A., PIEDRAS, S.R.N., PEREIRA, T.S.M. \& HOBUS, Q. 2007. Fauna selvagem e atropelamento.- diagnóstico do conhecimento científico brasileiro. In Áreas Protegidas. Repensando as escalas de atuação (A. Bager, ed.). Armazém Digital, Porto Alegre, p.49-62.

BEKKER, H. \& IUELL, B. 2003. Habitat fragmentation due to infrastructure. In International Conference on Ecology and Transportation (C.L. Irwin, P. Garrett \& K.P. McDermott, ed.). Lake Placid, New York, p.1-14

BENÍTEZ-LÓPEZ, A., ALKEMADE, R. \& PITA, A.V. 2010. The impacts of roads and other infrastructure on mammal and bird populations: a meta-analysis. Biol. Conserv. 143:1307-1316.

BERGALlO, H.G., GEISE, L., BONVICINO, C.R., CERQUEIRA, R., D'ANDREA, P.S., ESBERÁRD, C.E., FERNANDEZ, F.A.S., GRELLE, C.E., PERACCHI, A.L., SICILIANO, S. \& VAZ, S.M. 2000. Mamíferos. In A fauna ameaçada de extinção do estado do Rio de Janeiro (H.G. Bergallo, C.F.D. Rocha, M.A.S. Alves \& M. Van Sluyz, ed.). EDUERJ, Rio de Janeiro, p.125-143.

CÁCERES, N.C. 2002. Food habitats and seed dispersal by the White-Eared Opossum Didelphis albiventris in southern Brazil. Stud. Neotrop. Fauna \& Environm. 37:97-104.

CLEVENGER, A.P., CHRUSZCZ, B. \& GUNSON, K.E. 2003. Spatial patterns and factors influencing small vertebrate fauna road-kill aggregations. Biol. Conserv. 109:15-26.

COELHO, I.P., KINDEL, A. \& COELHO, A.V.P. 2008. Roadkills of vertebrate species on two highways through the Atlantic Forest Biosphere Reserve, southern Brazil. Eur. J. Wildl. Res. 54:689-699.

COFFIN, A.W. 2007. From roadkill to road ecology: a review of the ecological affects of roads. J. Transp. Geog. 15:396-406.

D'AIGNAUX, J.N.H., COUSENS, S.N. \& SMITH, P.G. 2001. Predictability of the UK Variant Creutzfeldt-Jakob Disease Epidemic. Science 294(5547):1729-1731

FINDER, R.A., ROSEBERRY, J.L. \& WOOLF, A. 1999. Site and landscape conditions at white-tailed deer/vehicle collision locations in Illinois. Land. Urban Plan. 44:77-85.

GLÄSSER, U. \& VAJIHOLLAHI, M. 2008. Computational modeling of criminal activity. In Intelligence and Security Informatics. Springer Berlin, Heidelberg, p.39-50.

GOMES, L., GRILO, C., SILVA, C. \& MIRA, A. 2009. Identification methods and deterministic factors of owl roadkill hotspot locations in Mediterranean landscapes. Ecol. Res. 24:355-370. 
GUMIER-COSTA, F. \& SPERBER, C.F. 2009. Atropelamentos de vertebrados na Floresta Nacional de Carajás, Pará, Brasil. Acta Amaz. 39(2):459-466.

HELS, T. \& BUCHWALD, E. 2001. The effect of road kills on amphibian population. Biol. Conserv. 99:331-340.

INDRUSIAK, C. \& EIZIRIK, E. 2003. Carnívoros. In Livro vermelho da fauna ameaçada de extinção no Rio Grande do Sul (C.S. Fontana, G.A. Bencke \& R.E. Reis, ed.). EDIPUCRS, Porto Alegre, p.507-533.

MALO, J.E., SUÁREZ, F. \& DÍEZ, A. 2004. Can we mitigate animal-vehicle accidents using predictive models? J. Appl. Ecol. 41:701-710.

MYERS, N., MITTERMEIER, R.A., MITTERMEIER, C.G., DA FONSECA, G.A.B. \& KENT, J. 2000. Biodiversity hotspots for conservation priorities. Nature 403:853-858.

NAKANO-OLIVEIRA, E., FUSCO, R., SANTOS, E.A.V. \& MONTEIROFILHO, E.L.A. 2004. New information about the behavior of Lontra longicaudis (Carnívora: Mustelidae) by radio-telemetry. IUCN Otter Spec. Group Bull. 21(1):3-35.

NOVELLI, R., TAKASE, E. \& CASTRO, V. 1988. Estudo das aves mortas por atropelamento em um trecho da rodovia BR-471, entre os distritos da Quinta e Taim, Rio Grande do Sul, Brasil. Revta Bras. Zool. 5(3):441-454.

OLIVEIRA, T.G. \& CASSARO, K. 2005. Guia de campo dos felinos do Brasil. Instituto Pró-Carnivoros, Sociedade de Zoológicos do Brasil, Fundação Parque Zoológico de São Paulo, São Paulo.

PEREIRA, A.P.F.G., ANDRADE, F.A.G. \& FERNANDES, M.E.B. 2006. Dois anos de monitoramento dos atropelamentos de mamíferos na rodovia PA-458, Bragança, Pará. Bol. Mus. Para. Emílio Goeldi 1(3):77-83.
PINOWSKI, J. 2005. Roadkills of vertebrates in Venezuela. Revta Bras. Zool. 22(1):191-196.

PRADO, T.R., FERREIRA, A.A. \& GUIMARÃES, Z.P.S. 2006. Efeito da implantação de rodovias no cerrado brasileiro sobre a fauna de vertebrados. Acta Sci. Biol. Sci. 28(3):237-241.

RAMP, D., CALDELL, J. \& EDWARDS, K.A. 2005. Modelling of wildlife fatality hotspots along the Snowy Mountain Highway in New South Wales, Australia. Biol. Conserv. 126:474-490.

ROGER, E. \& RAMP, D. 2009. Incorporating habitat use in models of fauna fatalities on roads. Divers. Distrib. 15:222-231.

ROSA, C.A., HOBUS, Q. \& BAGER, A. 2010. Mammalia, Pilosa, Myrmecophagidae, Tamandua tetradactyla (Linnaeus, 1758): Distribution extension. Check List 6(1):52-53.

TAYLOR, B.D. \& GOLDINGAY, R.L. 2004. Wildlife road-kills on three major roads in north-eastern New South Wales. Wildl Res. 31:83-91.

TORTOISE \& FRESHWATER TURTLE SPECIALIST GROUP. 1996. Acanthochelys spixii. IUCN Red List of Threatened Species, Version 2010.1. http://www.iucnredlist.org (último acesso em 08/04/2010).

TROMBULAK, S.C. \& FRISSELL, C.A. 2000. Review of ecological effects of roads on terrestrial and aquatic communities. Conserv. Biol. 14(1):18-30.

TURCI, L.C.B. \& BERNARDE, P.S. 2009. Vertebrados atropelados na Rodovia Estadual 383 em Rondônia, Brasil. Biotemas 22(1):121-127.

WAECHTER, J.L. \& JARENKOW, J.A. 1998. Composição e estrutura do componente arbóreo nas matas turfosas do Taim, Rio Grande do Sul. Biotemas 11(1):45-69. 
